\title{
Autologous-Autologous Tandem Hematopoietic Stem Cell Transplantation
}

National Cancer Institute

\section{Source}

National Cancer Institute. Autologous-Autologous Tandem Hematopoietic Stem Cell

Transplantation. NCI Thesaurus. Code C116466.

Therapy that combines cytoreductive-therapy from high-dose therapy and autologous hematopoietic cell transplantation with adoptive immunotherapy (from autologous hematopoietic cell transplantation) as a treatment strategy for multiple myeloma. 